\title{
Culture in Schooling in the Inuvialuit Settlement Region
}

\author{
Paul Berger, Lakehead University \\ Jennifer Johnston, Inuvialuit Regional Corporation \\ Melissa Oskineegish, Lakehead University
}

\begin{abstract}
We describe research on Inuvialuit culture in schooling in the Inuvialuit Settlement Region in the northwestern Northwest Territories in Arctic Canada. A mixed-methods case study using questionnaires in the region's six communities explored students', parents,' and high school teachers' perspectives on Inuvialuit culture in the schools. While students and parents were pleased that local culture is reflected in the schools, most would like to see more Inuvialuit culture become part of schooling. Teachers would like to know more about Inuvialuit culture and history and would like professional development to help them teach Inuvialuit students more effectively. This research suggests that policy in the Northwest Territories to move towards culturally responsive schooling is yet to be fully embodied. It should be prioritized.
\end{abstract}

Keywords: Arctic Canada; Inuvialuit education; culturally responsive schooling

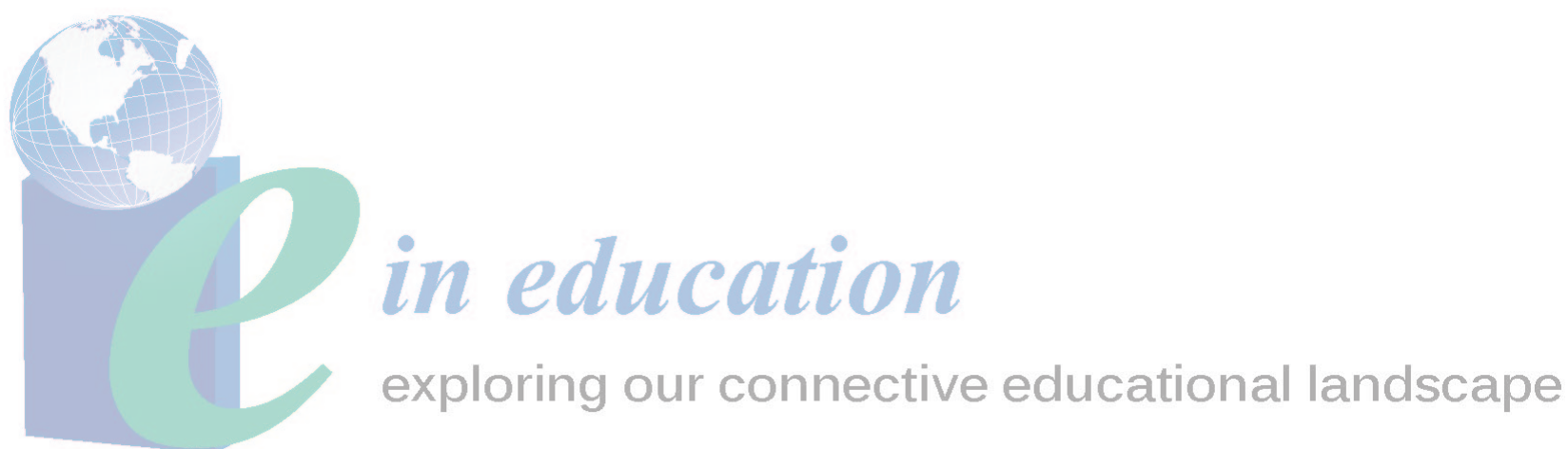




\section{Culture in Schooling in the Inuvialuit Settlement Region}

In Canada's Western Arctic, the Inuvialuit ${ }^{1}$ students of the Inuvialuit Settlement Region (ISR) ${ }^{2}$ have significantly lower school achievement than students in the rest of the Northwest Territories and Canada (Inuvialuit Regional Corporation [IRC], 2013). Despite recent changes to school policies and programming across the Northwest Territories and Nunavut, northern schools continue to operate primarily from a EuroCanadian framework with the majority of high school teachers arriving from the south (Aylward, 2009; Berger, 2009; McKechnie, 2014; Rasmussen, 2011). Culturally responsive schooling theory (e.g., Castagno \& Brayboy, 2008; LadsonBillings, 1995) suggests that Indigenous students may achieve more academic success with curriculum that reflects their culture and familiar pedagogy that prioritizes teacher-student relationships, and, that they also deserve a school environment that affirms their cultural identity. This article looks at students', parents' and high school teachers' perspectives on Inuvialuit culture in schooling in the ISR, using the lens of culturally responsive schooling and particularly what it can look like in Arctic contexts (e.g., Alaska Native Knowledge Network [ANKN], 1998; Barnhardt \& Kawagely, 2005). We argue that students' and parents' desires for more Inuvialuit culture in schooling must be honored, and that high school teachers' openness to learning about Inuvialuit culture, and improving their teaching of Inuvialuit students, creates an opportunity for growth towards more culturally responsive schooling.

\section{Culturally Responsive Schooling and Northwest Territories Education Policy}

There is a significant body of research suggesting that school achievement increases with teaching that uses the "cultural knowledge, prior experiences, frame of reference, and performance styles of ethnically diverse students to make learning more relevant to and effective for them" (Gay, 2010, p. 31) —often called culturally responsive schooling or teaching. Culturally responsive teachers get to know their students, their cultural heritage, and experiences (Villegas \& Lucas, 2002). They move beyond the superficial treatment of culture to develop and implement curriculum and pedagogical practices that are meaningful and relevant to the students they are teaching (Castagno \& Brayboy, 2008).

Much work has been done on culturally responsive schooling in Alaska where the ANKN (1998) published the Alaska Standards for Culturally Responsive Schools. The Standards call for cultural knowledge to be the basis for education rather than as something to be taught in schools as a subject. Barnhardt (2009) has written about how the environment and local culture can become the "foundation for all learning" (p. 4), the starting point and bridge to school knowledge, and particularly Western science. Lipka et al.'s (2005) work has, similarly, showed how students can succeed when mathematics instruction is based on familiar cultural practices. There is evidence that much work is necessary in schools in the Canadian Arctic to implement schooling that is responsive to the culture, traditions, language, and practices of the host communities (Higgins, 2011; Lewthwaite \& McMillan, 2010; McMillan, 2013).

Taking culture seriously in Arctic schooling has been frequently recommended, and parents across the north have long called for increases in local culture in their children's schooling (e.g., Berger, 2008; Arctic Institute of North America, 1973; Aylward, 2004; National Committee on Inuit Education, 2011; Northwest Territories Legislative Assembly Special Committee on Education, 1982; Tagalik, 2010). Nunavut, in the Eastern Arctic, is working to move Inuit ways and values into schooling (McGregor, 2012; Tagalik, 2010) and in the 
Northwest Territories there is a major emphasis in educational policy that suggests Inuvialuit culture should be prioritized in classrooms in the ISR. This policy includes the Aboriginal Language and Culture-based Education Departmental Directive (Northwest Territories Education Culture and Employment [NWT ECE], 2004), the Aboriginal Student Achievement Education Plan (NWT ECE, 2011), and the Education Renewal and Innovation Framework: Directions for Change (NWT ECE, 2013).

Lacking from the literature is research looking at Inuvialuit culture in ISR schools, what today's students and parents want in schools in terms of Inuvialuit culture, and how teachers, who are not from the region, see Inuvialuit culture and their ability to teach in a culturally responsive manner. This article contributes in these areas and suggests ways to build teacher capacity in culturally responsive teaching.

\section{The Study and Researchers}

The Inuvialuit Regional Corporation (IRC), ${ }^{3}$ looking to understand how to increase Inuvialuit student school achievement and to determine if NWT education policies adequately respond to the educational needs and realities of the Inuvialuit, initiated the study in cooperation with the Beaufort Delta Education Council. Questions related to Inuvialuit culture were one part of the broader research (Johnston \& Berger, 2014); they are the focus here. Jennifer, a EuroCanadian who had lived in Inuvik for seven years and had worked as a researcher for IRC for three years, led the research. Paul, a EuroCanadian, was asked by IRC to work with Jennifer in an advisory capacity. Paul taught Grade 7 in Nunavut in the 1990s and has conducted research meant to support Inuit in creating Nunavut schooling that meets the wishes and needs of Inuit. He teaches at Lakehead University in Thunder Bay, ON. Melissa, also EuroCanadian, joined in writing this article. She is a Ph.D. candidate at Lakehead University, working on reflective practice in teacher preparation for teaching Indigenous students.

In 2016, we are concerned about being three White people writing about Inuvialuit schooling. We are somewhat comforted that the research was initiated by an Inuvialuit organization and that we presented the research findings on two occasions to the Beaufort Delta Education Council-an elected steering committee for the schools in the ISR - which is using the report on the broader study in the professional development of area teachers.

\section{A Mixed-Methods Case Study Using Questionnaires}

As a case study (Yin, 2003) on Inuvialuit culture in schooling in the ISR, this mixed-methods research used questionnaires (Gay, Mills, \& Airasian, 2009) to determine youth, parent, and teacher views about culture in schooling in the ISR. Youth and parents in the ISR communities were invited to take part in IRC youth and parent questionnaire in March, 2013. Criteria for youth participation included being in Grades 7 - 12 or having attended high school within the last five years. Criteria for parent participation included having a child or children in Grades 7 - 12 or having children who attended high school within the last five years. Both youth and parents heard about the research through a community presentation, advertising via radio, flyers placed at their door, a phone call to homes identified on IRC's Inuvialuit Beneficiary list, or information from IRC disseminated in schools by teachers and principals. Participation was voluntary and participants' identities protected. Those administering the questionnaires were instructed to allow participants to not answer any question and to stop the interview if participants felt uncomfortable. They had contact information so they could refer participants for health or mental 
well-being support if they because very upset during completion of the questionnaire.

The youth questionnaires for the broader research included 53 questions, some with multiple parts. The question types included: demographic; Likert Scale response with 5 point scale from "strongly agree" to "strongly disagree"; choose the best answer; one or several word answers; choose all that apply; yes/no; rating scale questions; and open-ended questions. Some questions were directly related to Inuvialuit culture in schooling, such as, What about this region and its people would you like your teachers to know, or know more about? In others, the connection was more tangential; for example, "missing hunting” was reported in answer to: What would be the pros and cons of moving away for schooling? For this reason, it is not possible to say that a certain number of the questions were culture-related and used in the analysis. Examples of some key questions are given in reporting the findings. The parent questionnaires included 49 questions, of similar types.

Questionnaire completion took place in participants' homes or an office identified by Jennifer or an IRC Community Field Worker (CFW), typically an Inuvialuit community member, trained by her. Jennifer asked the questions and recorded answers for 20 students and the CFWs for 140 students, while she completed questionnaires with 50 parents and while CFWs did this with 87 parents. The questionnaires took between 20 - 30 minutes to complete for youth and 30 - 40 minutes for parents.

Teachers were invited to take part in the IRC teacher questionnaire in September, 2013. The questionnaires were designed, following a preliminary analysis of the student and parent questionnaires, to get teachers' ideas about some of the salient issues identified by parents and students. Teachers were sent an electronic version distributed to the regions' high school teachers by the Supervisor of Schools to print, complete, and mail back to the IRC, and four weeks later a link to an online version on Survey Monkey. The teacher questionnaire included 36 Likert scale questions and four open-ended questions. The questions focused on teachers' experiences and thoughts about teaching Inuvialuit students in the ISR. Some examples appear in the reporting of key findings.

\section{Participants}

Of the 160 youth who completed the questionnaire, 97 were female, 62 male, and one unknown. Students in Grades 7 - 12 made up 76\%, with most from Grades 10 - 12. Three percent were graduates, nine percent had stopped school, and two percent were in alternative programs. Participants were informed that they could decline to answer any question, and not all questions were relevant for all participants, so the actual number of respondents varied across questionsincluding for this one where data on grade is missing for $10 \%$ of youth participants.

With just 1200 students in ISR K-12 schools (Beaufort District Education Council, n. d.), approximately 550 of whom are in Grades 7 - 12, this sample of 160 high school students and recent students captured data from about $22 \%$ of all high school students across the six communities in the ISR. Students received a \$50 gift certificate to the local store for participating. This, and the fact that adults who could be perceived as being connected to the schools facilitated the questionnaire completion, may have biased the sample, and we do not claim that our interpretations represent all ISR high school students; we do, however, believe that with this large sample from all communities there is reason to pay attention to the findings. 
Most of the 137 parent respondents were Inuvialuit (95\%), with a small number of Métis, Gwich'in, and other Indigenous peoples. More women than men, by almost three to one, completed the parent questionnaire, though nine participants did not declare their gender or specify "other." At the time of the interview, the majority (92\%) of respondents had at least one child in high school. As with the students, we cannot claim that what we report represents all Inuvialuit parents in the ISR, but with a large sample drawn from all communities, we have confidence that the views expressed will be recognizable to people in the region.

The teacher questionnaire asked teachers about their personal cultural background to determine the number of local versus Southern (originating from southern Canada; for convenience, we use "EuroCanadian") teachers. About $75 \%$ of the 37 participants were EuroCanadian, with a range of experience teaching in the ISR from just beginning to over seven years. There are approximately 45 high school teachers in the ISR (BDEC, n. d.), most of whom are EuroCanadian. Responses to the questionnaire from nine Indigenous educators lead us to believe that the questionnaires may have been distributed more widely than to just high school teachers because there are fewer than nine Indigenous high school teachers in the region. The sample was not random and voluntary participation may have biased the sample; still, 28 EuroCanadian high school teachers represent well over half of EuroCanadian high school teachers in the ISR.

Descriptive statistics such as the percentage distribution of answers to Likert Scale questions were calculated and are reported here. Although this article focuses on Inuvialuit in the Western Arctic, many Arctic communities share similar histories, schooling history and socioeconomic conditions (Darnell \& Hoem, 1996), and these communities may recognize our findings and judge some of the recommendations to be relevant.

\section{Student, Parent and Teacher Perspectives}

Here we provide a description of Inuvialuit students', parents,' and primarily non-Indigenous educators' perspectives on cultural knowledge and content included in schools. Each group acknowledges the presence and importance of Inuvialuit culture in ISR schools. Many parents and students want an increase and most teachers are open to learning more.

\section{Inuvialuit Students' Perspectives}

The youth questionnaire asked a number of questions about the presence of Inuvialuit culture in schools and curriculum, with some of the questions focusing on the knowledge and awareness that teachers possessed of Inuvialuit and the ISR. ${ }^{4}$ Although almost none of the teachers in Grades 7 - 12 are from the ISR, almost three-quarters of youth "agreed" or "strongly agreed" that their teachers were "aware of the history" of the region and its people, while about 19\% “disagreed” or strongly “disagreed” and eight percent answered “don’t know.” Ninety-five percent of the youth said that their school "respects/honours the cultural backgrounds of students.” These are very encouraging findings, although students would still like teachers and the schools to pay more attention to culture.

The open-ended question: "What about this region and its people would you like your teachers to know, or know more about?” was answered by 114 people. Their answers were coded for everything they named. Culture was referred to most frequent at $51 \%$, land at $25 \%$ and language at $11 \%$. Residential School history was recorded by eight percent and six percent said 
"nothing." While deep knowledge and understanding might take many years to acquire (McMillan, 2015), one participant identified what might be key, saying: "I am okay if they are not aware as long as they are open to learning." With a respectful attitude and willingness to learn, teachers new to the Arctic can make great strides (Tompkins, 2006).

Current territorial government policy is aimed at increasing teachers' knowledge of Inuvialuit culture and history (NWT ECE, 2013) and culturally responsive teaching theory suggests it could increase student achievement and well-being (Castagno \& Brayboy, 2008). For example, cultural difference in Inuit schools in Northern Quebec led EuroCanadian teachers to scold students for "cheating" when Inuit teachers would have encouraged the same peer helping behaviour-connected as it was to the deep Inuit cultural value of cooperation (Crago, EriksBrophy, Pesco, \& McAlpine, 1997). Western school values can clash strongly with Inuvialuit values (Brody, 2000; Douglas, 1998; Okakok, 1989). Understanding this can help teachers avoid, and solve, conflicts.

Youth were asked about the optimum level of Inuvialuit cultural content in school; 154 answered and eight provided additional comments. Some-17\% — checked "there is enough Inuvialuit cultural content." One comment illustrates: "I respect culture, but school should be separate." The other 83\% of respondents wanted more Inuvialuit cultural content, with 36\% checking "there should be more Inuvialuit culture in a few courses," 11\% checking "there should be more Inuvialuit culture in every course," 20\% checking "there should be a course devoted to Inuvialuit culture," and 16\% checking "there should be more in every course and a course devoted to Inuvialuit culture." The majority of youth participants thought that their teachers were respectful of Inuvialuit culture, but there remains a strong call for more Inuvialuit culture in schooling. This finding resonates with the desire for more culture expressed by Inuit students and parents in Nunavut in the Eastern Arctic (Aylward, 2004; Berger, 2008).

It should be noted that the option to indicate the need for a deeper school redesign - that would see schooling based in Inuvialuit values and culture instead of trying to add them into the current EuroCanadian system-was not offered on the questionnaire. Such a school system, or a truly bicultural one, would mean a strong possibility for student success and well-being (Barnhardt, 2009; T. R. Berger, 2006). Simply adding "Inuvialuit culture" into the existing school program and courses does not address the power imbalance that is at the root of colonialism, or the imperative to protect rather than transform Inuvialuit identity (see Tagalik, 2010). Without deep change, adding culture will not lead to culturally responsive schooling that affirms Inuvialuit identity (see Ladson-Billings, 1995).

\section{Inuvialuit Parents’ Perspectives}

Inuvialuit culture and history are intimately connected to the land and $73 \%$ of parents said their child takes part in school-based on-the-land activities. When parents were asked for the number of days children spent with family on the land during the school year, $44 \%$ reported four to 10 days, and $10 \%$ reported spending more than 10 days. The land and land activities remain very important for many Inuvialuit (Johnston, 2007), and we expect more would have been reported if the cost of equipment for land travel were not so high (see Berger, 2008).

We asked whether there had been "more than three times in any year when your own family's on-the-land activities have conflicted with school.” Of the 107 parents who answered, half responded "yes." This resonates with a long-standing tension in Arctic schooling. School 
takes such a large chunk of time that it would be very difficult to become an expert in land skills while attending full-time (Henze \& Vanett, 1993), and yet the way Western school curriculum is organized, missing chunks of time at school can mean missing key concepts or techniques (Macquire \& McAlpine, 1996). Having students complete modules with guidance might help students with many absences continue to make progress (Berger, 2008), but there is no easy solution. If EuroCanadian teachers understand the crucial importance of land activities to the education of Inuvialuit students, they should be able to respond with respect when students miss school because they are on the land with their families.

Parents were asked if they thought there was enough cultural content in what their child was learning. Out of 129 parents who responded to this question, 13\% chose "yes, there is enough Inuvialuit cultural content" and 87\% expressed a need for more. Over a third indicated the highest option presented-that "there should be more in every course and a course devoted to Inuvialuit culture." The strong desire for more Inuvialuit culture in schooling continues an unbroken chain of findings that Inuvialuit and Inuit across the Arctic want schools to include more of their culture (e.g., AINA, 1973; Aylward, 2004; Berger, 2008; GNWT, 1982; Nunavut Department of Education, 2006). Related to the amount of Inuvialuit content in schooling, 94\% of parents agreed or strongly agreed that it is important for teachers to have awareness of the region, people and culture.

Many parents-77\% - said they saw evidence of Inuvialuit culture in the schools, and most parents-89\% — said that they feel comfortable in their child's school. The majority$74 \%$ - said they are often invited to be involved in decisions at their child's school. These numbers are very positive. Local control is thought to be important in parental support for schools and in student success and well-being (Cummins, 1986; Harrison, 1993; Lipka, 1989). As McMillan (2015) wrote in the Nunavut context, Indigenous people must, in fact, be in control of policy, curricula, and the school system (p. 25). Involving parents in decisions is one step towards local control and it sends a message of respect. More investigation is needed to describe the type of decisions parents have been involved in, and what the involvement has looked like.

It is also positive that so many parents reported feeling comfortable in the schools. With the legacy of Residential Schooling and traumatic experiences in local schools, it is understandable when Indigenous parents feel uncomfortable in schools (Kavik, 2007). While it is possible that parents who feel comfortable in schools might have been more likely to participate in this research than parents who do not, biasing the findings, the findings suggest that efforts are made by teachers and administrators to welcome parents and to reflect the communities in the schools. This is a good base on which to build efforts to bring more Inuvialuit culture into schooling.

\section{Teachers' Perspectives}

Thirty-seven educators, most of whom were non-Indigenous high school teachers, were asked a series of questions concerning their views on culture and its relevance to learning. Overall, there is a high level of awareness that culture is important. Most $(78 \%, \mathrm{~N}=29)$ believed that a strong cultural identity is important in Inuvialuit student success, and the same number reported that their schools and classrooms welcomed Elders and community members. A few answered "neutral" to these questions. This may reflect some ambiguity; for example, if a teacher wants to include Elders but feels that there are no funds to support doing so, "neutral” 
may have been chosen. It may, however, indicate resistance to the idea that local culture is important in schooling. In cases where teachers are resistant to the idea that schooling must reflect the culture of the students, Tompkins (2006), a past principal in Nunavut, found that it was very difficult to help them become culturally responsive teachers. She recommended trying to avoid hiring such people.

Teachers were also asked whether "there is enough Inuvialuit content in the curriculum." Here, the participant responses were more mixed. Many either "strongly agreed" (eight percent) or “agreed” (38\%), with 27\% "neutral” and 24\% “disagreeing” or "strongly disagreeing.” Asked whether "a strong sense of Aboriginal cultural heritage and identity is fostered in the school in which I teach,” 74\% answered "strongly agree” or “agree.”

While there is considerable danger of misinterpreting educators' responses, and we recommend further research that engages educators in the ISR in conversations, we interpret these findings in the following way. The curriculum of schools in the ISR remains largely EuroCanadian, with much more work to be done in creating Inuvialuit curriculum and shifting school practices to being grounded in Inuvialuit ways and values. There may be considerable work needed to help EuroCanadian teachers to understand how deeply Eurocentrism structures Arctic schooling and how much work needs to be done to change that (McKechnie, 2014). It is positive that most teachers acknowledged the importance of culture and cultural identity. In a larger study of EuroCanadian teachers in Nunavut, Aylward (2009) also found that teachers acknowledged the importance of culture, but maintained Eurocentric beliefs about culture in schooling. EuroCanadian teachers occupy the awkward position of being agents of colonialism.

In a related question, when asked whether "a school focus on individual achievement may cause tension for students from a culture that values cooperation," 49\% "strongly disagreed" or "disagreed," 29\% answered "neutral," and only 22\% “agreed.” This is not surprising, since many EuroCanadians are socialized to not need to think about cultural difference, as almost everything in southern Canada functions on EuroCanadian norms (Schick, 2000). As Mi'kmaq scholar Marie Battiste (2005) wrote, we have all been marinated in Eurocentric thought. As the questions suggests, however, there is strong evidence that at the level of deep values, Western schooling and Indigenous cultures have significant clashes (Brody, 2000; Douglas, 1998; Henze \& Vanett, 1993; Okakok, 1989) and students suffer because of it (Stairs, 1991). When teachers are not aware of the tensions value differences can create, they are unable to consciously address them to avoid the problem or mitigate the damage. Fortunately, most teachers indicated the desire to learn more about teaching in the contexts of the ISR-including teaching across cultures.

\section{Looking Forward: Increasing Teacher Capacity}

Most high school teachers in the ISR are of EuroCanadian descent and are from outside of the communities and the Western Arctic. It can, therefore, be assumed that in most cases their initial knowledge of the people, culture, and history of the region would be limited. Their initial teacher education was very likely inadequate in preparing them to teach in Indigenous contexts (Harper, 2000; Oskineegish, 2013). Thus, actions taken after arrival are important in the success of the teaching experience, in reducing the rate of staff turnover, and in increasing the degree of connection between the school and community. We asked the teachers questions regarding the preparation they received prior to arriving in the region and their learning about the community 
and people after arriving. We asked whether they had modified their teaching style, and about their desire to learn more about teaching Inuvialuit students.

Overall, teachers felt underprepared, had learned much on the job, and would like to learn more. Asked about preparation prior to arrival, 76\% did not feel "well versed" in "the cultural and historical context of the region," though 91\% did come to feel so in the time they had spent teaching in the region. Teachers are clearly open to learning despite the already steep learning curve of teaching in a new place and culture and the busyness this entails. Almost all-97\%indicated that "I would like to learn more about local knowledge and culture," and 89\% that they "would like to learn more about the history of the region and the people who live here."

In an open-ended question, teachers were asked how they would prefer to learn more about the region's people and culture. Thirty-three people responded and the most prevalent method of learning involved interfacing with the community, by inviting or continuing to invite Elders and other informal cultural resource people into the classroom to share knowledge, history, and experiences, and by learning in a hands-on manner outside of the classroom, on the land or in the community. One teacher noted that the in-servicing opportunities of the Northern Studies teacher should be available to all teachers. Another wrote:

I would like to learn in the context of active learning. 'On the land' experiences at Reindeer Station and other significant sites would be useful. Also, learning in a context which is easily transferable to student learning would be an asset. (Teacher Respondent, questionnaire, September 2013)

This sentiment resonates strongly with Barnhardt and Kawagely's (2005) work in Alaska, documenting the power of land camps and Elders to ground learning about Western science in local experience-building bridges to Western curriculum and educating EuroCanadian teachers.

While some of the preferred ways to learn could be pursued independently of the schools, and may need to be if McKechnie's (2014) thoughts on the lack of government capacity to provide adequate professional development are correct, active facilitation by school leadership would be very beneficial (Aylward, 2009). Sufficient funds to pay Elders for teaching and for leading land experiences will be essential.

Teachers overwhelmingly (91\%) indicated that they had modified their teaching styles for the cultural contexts of their classes, and that they would like to learn teaching techniques to be better teachers of Inuvialuit students (83\%). An open-ended question about how teachers would prefer to learn more about teaching Inuvialuit students was answered by 24. A number of people wrote something general, such as "professional development," while others were more specific; for example, "through targeted professional development and resources" or "What works? What doesn't, and why?” Participants wrote that they would like to learn through observation, or observations of a master teacher, and through dialogue with other teachers. Reading, online learning and presentations were mentioned, as were "research and in-class practice." Teachers mentioned learning from the community and "hands-on.” Learning preferences varied widely. The idea of focused professional development from people who are "specialists” or who have "extensive training and experience teaching Aboriginal students" was strongly expressed. 
In related questions, $74 \%$ of teachers indicated that they have a good relationship with the parents of their students, and 86\% indicated that they would like to know more about engaging parents in their children's learning. These are also encouraging results, and it is possible that professional development focused on Inuvialuit culture, closer ties with the community, and greater parental engagement may be approached concurrently as community members are invited into classrooms to share knowledge and skills. Some authors recommend collaboration with community members for learning in Arctic schooling (e.g., ANKN, 1998; McMillan, 2015, Walton et al., 2014). Whalan and Wood's (2012) Australian model of action learning with community members may be especially useful.

It is very promising that a large majority of teachers indicated the desire to learn more about teaching Inuvialuit students. There is substantial evidence that Indigenous students struggle when asked to learn in unfamiliar ways without support (e.g., Castagno \& Brayboy, 2008; Faircloth \& Tippeconnic, 2010). EuroCanadian teachers can become more effective in teaching Inuvialuit students. They can build cultural knowledge by engaging in the community where they are teaching (Higgins, 2011; Lewthwaite, Owen, Dorion, McMillan, \& Renaud, 2013; McMillan, 2013; Tompkins, 2006) and from the relationships with students, colleagues, and community members (Oskineegish \& Berger, 2013; Pashagumskum, 2014). Just knowing about cultural differences can help them avoid misjudging the ability of their students (Crago \& Eriks-Brophy, 1994), while knowing the history of colonialism, including Residential Schools, can help teachers understand and respond with respect to the social challenges faced by many (Goulet, 2001). Locally relevant curriculum can provide a vehicle for thoughtful teachers to learn along with their students (McGregor, 2012; McKechnie, 2014; McMillan, 2015).

Based on participants' comments, it is not possible to recommend one particular type of professional development since the teachers' needs and preferences vary. Drawing on local and regional expertise and creating many opportunities for teachers to share best practices is needed. Over 40 years ago, AINA (1973) recommended a university course to orient new teachers to Arctic realities, a four-week intensive orientation, and five months of continued intensive training as the northern teaching career began. Given the enormity of learning a new culture and worldview (McMillan, 2015), that could provide a good start. The more support that can be provided, the better. Our findings suggest that, like teachers across the Arctic (Berger \& Epp, 2007) and in other Indigenous settings (Harper, 2000), teachers in the ISR are eager to become more effective and ready and willing to learn.

\section{Conclusion}

Most students and parents want more Inuvialuit culture in the schools and most teachers would like to learn more about Inuvialuit culture and teaching Inuvialuit students. While basing high school on Inuvialuit rather than EuroCanadian culture would require a complete redesign of formal schooling and very many Inuvialuit teachers and administrators, our findings are promising for the continuing efforts to move Inuvialuit culture into the schools. Official policy, such as the NWT ECE Aboriginal Student Achievement Plan (2011), confirms the importance of local culture and the need for students to be proud of who they are, and acknowledges that this depends on teachers. There are broader issues to attend to as well, such as the role of colonialism and its impact on communities. Students, parents and teachers in this research were well aware of these problems, and they are discussed in territorial policy (NWT ECE, 2013). Strongly moving more Inuvialuit culture into schools will help. 
Policy in the ISR calls for more Inuvialuit culture in schooling. Students and parents indicated their desire for more. High school teachers signaled their desire to learn. Literature on culturally responsive teaching suggests that professional development connected to communities can be powerful (Castagno \& Brayboy, 2008). The time is right to work together on moving Inuvialuit culture more strongly into formal schooling. 


\section{References}

Alaska Native Knowledge Network. (1998). Alaska standards for culturally responsive schools. Author. Retrieved from http://www.ankn.uaf.edu/publications/standards.html

Arctic Institute of North America. (1973). Man in the North technical paper: Education in the Canadian North-Three reports: 1971 - 1972. Montreal, PQ: Author.

Aylward, M. L. (2004). Summary report of the Sivuniksamut Ilinniarniq Consultations. Iqaluit, NU: Nunavut Department of Education.

Aylward, M. L. (2009). Culturally relevant school in Nunavut: Views of secondary school educators. Etudes/Inuit/Studies, 33(1/2), 77 - 93.

Barnhardt, R. (2009). Alaska Native Knowledge Network: Connecting education to place. Connect, Sept./Oct., 4 - 8.

Barnhardt, R., \& Kawagely, A. O. (2005). Indigenous knowledge systems and Alaska Native ways of knowing. Anthropology \& Education Quarterly, 36(1), 8 - 23.

Battiste, M. (2005). You can't be the global doctor if you're the colonial disease. In P. Tripp \& L. Muzzin (Eds.), Teaching as activism: Equity meets environmentalism (pp. 121 - 133). Monteal, PQ: McGill-Queen's University.

Beaufort District Education Council. (n. d.). Home: Our schools. Retrieved from http://www.bdec.nt.ca/

Berger, P. (2008). Inuit visions for schooling in one Nunavut community. (Unpublished doctoral dissertation). Lakehead University, Thunder Bay, Ontario, Canada.

Berger, P. (2009). Inuit language, culture, and parental engagement in schooling in one Nunavut community. Canadian Journal of Native Education, 32(1), 73 - 92.

Berger, P., \& Epp, J. (2007). “There’s no book and there’s no guide”: The expressed needs of Qallunaat educators in Nunavut. Brock Education, 16(2), 44 - 56.

Berger, T. R. (2006). “The Nunavut project”: Conciliator's final report. Report on the Nunavut Land Claims Agreement implementation contract negotiations for the second planning period 2003 - 2013. Retrieved from http://www.ainc-inac.gc.ca/pr/agr/nu/lca/nlc_e.pdf

Brody, H. (2000). The other side of Eden: Hunters, farmers and the shaping of the world. Toronto, ON: Douglas and McIntyre.

Castagno, A., \& Brayboy, B. (2008). Culturally responsive schooling for Indigenous youth: A review of the literature. Review of Educational Research, 78(4), 941 - 993. doi:10.3102/0034654308323036

Crago, M. B., \& Eriks-Brophy, A. (1994). Culture, conversation, and the co-construction of interaction: Implications and applications for intervention. In J. F. Duchan, L. E. Hewitt, \& R. M. Sonnenmeier (Eds.), Pragmatics: From theory to practice (pp. 43 - 58).

Englewood Cliffs, NJ: Prentice Hall. 
Crago, M. B., Eriks-Brophy, A., Pesco, D., \& McAlpine, L. (1997). Culturally based miscommunication in classroom interaction. Language, Speech, and Hearing Services in Schools, 28(3), 245 - 254.

Cummins, J. (1986). Empowering minority students. Harvard Educational Review, 56(1), 18 36. doi: 10.17763/haer.56.1.b327234461607787

Darnell, F., \& Hoem, A. (1996). Taken to extremes: Education in the far North. Oslo, NO: Scandinavian University Press.

Douglas, A. S. (1998). “There's life and then there's school”: School and community as contradictory contexts for Inuit self/knowledge. (Unpublished doctoral disseration). McGill University, Montreal, PQ, Canada.

Faircloth, S. C., \& Tippeconnic, J. W. (2010). The dropout/graduation rate crisis among American Indian and Alaska Native students: Failure to respond places the future of Native peoples at risk. Retrieved from: http://www.civilrightsproject.ucla.edu/

Gay, G. (2010). Culturally responsive teaching: Theory, research, and practice (2 ${ }^{\text {nd }}$ ed.). New York, NY: Teachers College Press.

Gay, L. R., Mills, G. E., \& Airasian, P. W. (2009). Educational research: Competencies for analysis and applications ( $9^{\text {th }}$ ed). Upper Saddle River, NJ: Merrill/Pearson Hall.

Government of Northwest Territories (GNWT). (1982). Learning, tradition and change in the Northwest Territories. Yellowknife, NWT: Northwest Territories Legislative Assembly Special Committee on Education.

Goulet, L. (2001). Two teachers of Aboriginal students: Effective practice in sociohistorical realities. Canadian Journal of Native Education, 25(1), 68 - 82.

Harper, H. (2000). “There's no way to prepare for this”: Teaching in First Nations schools in northern Ontario-issues and concerns. Canadian Journal of Native Education, 24(2), $144-157$.

Harrison, B. (1993). Building our house from the rubbish tree: Minority-directed education. In E. Jacobs \& C. Jordan (Eds.), Minority education: Anthropological perspectives (pp. 147 164). Noorwood, NJ: Ablex.

Henze, R., \& Vanett, L. (1993). To walk in two worlds or more? Challenging a common metaphor of Native education. Anthropology and Education Quarterly, 24(2), 116 - 134.

Higgins, M. (2011). Finding points of resonance: Nunavut students’ perspectives on science. in education, 17(3), 17 - 37.

Inuvialuit Regional Corporation (IRC). (2013, April 14). Inuvialuit indicators. Retrieved from http:/inuvialuitindicators.com

Inuvialuit Regional Corporation. (n. d.). Brief history. Retrieved from: http://www.irc.inuvialuit.com/about/history.html 
Johnston, J. (2007). A Qualitative study of the Inuvialuit practice of "going out on the land". (Unpublished master’s thesis). Royal Roads University, Victoria, BC, Canada.

Johnston, J. \& Berger, P. (2014). Inuvialuit Settlement Region perspectives on education in the Beaufort Delta. Inuvialuit Regional Corporation.

Kavik, L. (2007, February 5). CBC Radio Sounds Like Canada. (S. Rodgers, Interviewer)

Ladson-Billings, G. (1995). Toward a theory of culturally relevant pedagogy. American Educational Research Journal, 32(3), 465 - 491.

Lewthwaite, B., \& McMillan, B. (2010). "She can bother me, and that's because she cares": What Inuit students say about teaching and their learning. Canadian Journal of Education, 33(1), 140 - 175.

Lewthwaite, B., Owen, T., Doiron, A., McMillan, B., \& Renaud, R. (2013). Our stories about teaching and learning: A pedagogy of consequence for Yukon First Nation settings. Interchange, 44, 105 - 128.

Lipka, J. (1989). A cautionary tale of curriculum development in Yup’ik Eskimo communities. Anthropology and Education Quarterly, 20(3), 216 - 231.

Lipka, J., Hogan, M. P., Webster, J. P., Yanez, E., Adams, J. P., Clark, S., \& Lacy, D. (2005). Math in a cultural context: Two case studies of a successful culturally based math project. Anthropology and Education Quarterly, 36(4), 367 - 385.

Macquire, M., \& McAlpine, L. (1996). Attautsikut/together: Understanding cultural frames of reference. Alberta Journal of Educational Research, 42(3), 218 - 237.

McGregor, H. (2012). Curriculum change in Nunavut: Toward Inuit Qaujimajatuqangit. McGill Journal of Education, 47(3), 285 - 302.

McKechnie, J. (2014). Reconciling the role of a Quallunaat teacher in Nunavut. Radical Pedagogy, 11(20). Retrieved from http://www.radicalpedagogy.org/radicalpedagogy.org/Reconciling_the_Role_of_a_Qallu naat_Teacher_in_Nunavut_files/McKechnie.pdf

McMillan, B. (2013). Inuit legends, oral histories, art, and science in the collaborative development of lessons that foster two-way learning: The return of the sun in Nunavut. Interchange, 43, 129 - 145.

McMillan, B. (2015). Educating for cultural survival in Nunavut: Why haven't we learned from the past? Paideusis, 22(2), 24-37, Retrieved from http://journals.sfu.ca/pie/index.php/pie/article/view/421/225

National Committee on Inuit Education. (2011). First Canadians, Canadians first: National strategy on Inuit education 2011. Ottawa, ON. Inuit Tapiriit Kanatami.

Northwest Territories Education Culture and Employment (NWT ECE). (2004). Aboriginal language and culture based-education departmental directive. Retrieved from: http://www.ece.gov.nt.ca/files/EarlyChildhood/directives/Aboriginal\%20Language\%20a nd\%20Culture\%20Based\%20Education\%20Dept\%20Directive.pdf 
Northwest Territories Education Culture and Employment (NWT ECE). (2011, August).

Aboriginal student achievement education plan. Retrieved from:

https://www.ece.gov.nt.ca/files/Early-

Childhood/asa/ASA\%20Education_Plan_Final\%20Document.pdf

Northwest Territories Education Culture and Employment (NWT ECE). (2013). Education renewal and innovation framework: Directions for change. Retrieved from: https://www.ece.gov.nt.ca/files/ERI/eri_framework_tabled.pdf

Northwest Territories Legislative Assembly Special Committee on Education. (1982). Learning, tradition and change in the Northwest Territories. Yellowknife, NWT: Northwest Territories Information.

Nunavut Department of Education. (2006, May 26). Made-in Nunavut Education Act: What we've heard from Nunavummiut so far. (Newsletter in Nunatsiaq News). Iqaluit, NU: Author.

Okakok, L. (1989). Serving the purpose of education. Harvard Educational Review, 59(4), 405 422.

Oskineegish, M. (2013). How can non-Native teachers develop culturally responsive programs in remote First Nations communities? Learning from the experts. (Unpublished master's thesis). Lakehead University, Thunder Bay, ON, Canada.

Oskineegish, M., \& Berger, P. (2013). The role of the non-Native teacher in remote First Nations communities in northern Ontario. Canadian Journal of Native Education, 36(1), 113 125.

Pashagumskum, S. (2014). First Nations student engagement in secondary school: Enhancing student success in a northern Eeyou community. (Unpublished doctoral dissertation). Lakehead University, Thunder Bay, ON, Canada.

Rasmussen, D. (2011). Forty years of struggle and still no right to Inuit education in Nunavut. Interchange, 42(2), 137 - 155.

Schick, C. (2000). 'By virtue of being White': Resistance in anti-racist pedagogy. Race Ethinicity and Education, 3(1), 83 - 102.

Stairs, A. (1991). Learning processes and teaching roles in Native education: Cultural base and cultural brokerage. The Canadian Modern Language Review, 47(2), 280 - 294.

Stake, R. E. (1995). The art of case study research. Thousand Oaks, CA: Sage.

Tagalik, S. (2010). Inuit Qaujimajatuqangit: The role of indigenous knowledge in supporting wellness in Inuit communities in Nunavut. Prince George, BC: National Collaborating Centre for Aboriginal Health. Retrieved from http://www.nccahccnsa.ca/en/publications. aspx ?sortcode $=2.8 .10 \&$ publication $=6$

Tompkins, J. (2006). Critical and shared: Conceptions of Inuit educational leadership. (Unpublished doctoral disseration). University of Toronto, Toronto, ON, Canada. 
Villegas, A. M., \& Lucas, T. (2002). Preparing culturally responsive teachers: Rethinking the curriculum. Journal of Teacher Education, 53(1), 20 - 32.

Walton, F., O’leary, d., Metuq, L., Hainnu, J., Pitsiulak, S., Flaherty, E., Eejeesiak, N., Merkosak, J., \& Wheatley, K. (2014). This school feels like ours now; It belongs to the community: Engaging parents and Inuit educational leaders in policy change in Nunavut. [Special Issue ]Northern Public Affairs, 2, 49 - 52. Retrieved from http://www.northernpublicaffairs.ca/index/wp-content/uploads/2016/03/NPA-Vol-2Special-Issue-Walton-et-al.pdf

Whalan, F. \& Wood, K. (2012). Action learning based professional development. In N. Burridge, F. Whalan, \& K. Vaughan (Eds.), Indigenous education: A learning journey for teachers, schools and communities (pp. 23 - 32). Rotterdam, NL: Sense.

Yin, R. K. (2003). Case study research: Design and methods ( $3^{\text {rd }}$ ed.). Thousand Oaks, CA: Sage.

\section{Endnotes}

${ }^{1}$ Inuvialuit are Inuit peoples of the western Arctic.

${ }^{2}$ The ISR comprises the communities of Inuvik, Tuktoyaktuk, Paulatuk, Aklavik, Sachs Harbour and Ulahaktok.

${ }^{3}$ The IRC represents the Inuvialuit beneficiaries in the ISR under the 1984 Western Arctic Claims Settlement Act (IRC, n. d.).

${ }^{4}$ The questions used the term 'Beaufort Delta Region' rather than Inuvialuit Settlement Region. It is a slightly larger region that includes two communities that are not part of the ISR. 